\title{
Intermediate Coronary Artery Disease Risk
}

National Cancer Institute

\section{Source}

National Cancer Institute. Intermediate Coronary Artery Disease Risk. NCI Thesaurus. Code $C 99966$.

The likelihood an individual will develop coronary artery disease (CAD) is moderate or between 10\% and 90\%. (Gibbons RJ, Balady GJ, Bricker JT, Chaitman BR, Fletcher GF, Froelicher VF, Mark DB, McCallister BD, Mooss AN, O'Reilly MG, Winters WL Jr. ACC/AHA 2002 guideline update for exercise testing: a report of the American College of Cardiology/American Heart Association Task Force on Practice Guidelines (Committee on Exercise Testing). 2002. American College of Cardiology Web site. Available at: www.acc.org/clinical/guidelines/exercise/dirlndex.htm.) (ACC) 